\title{
DISC'LAIMER
}

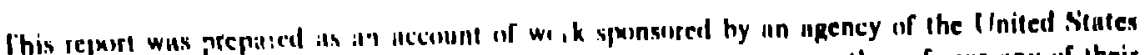
Geres

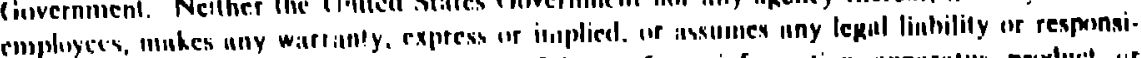

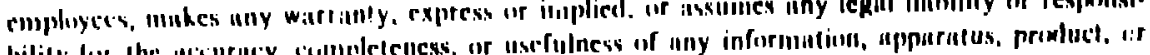

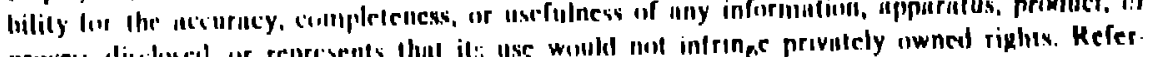

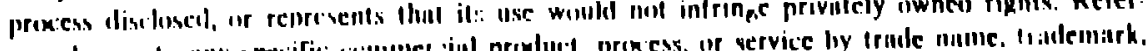

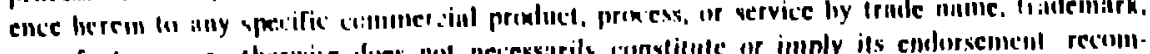

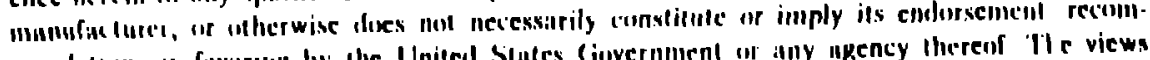

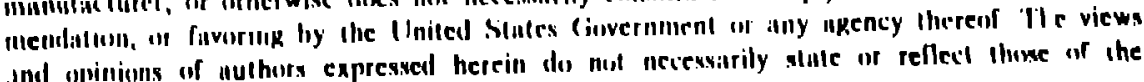
United Situles diovernment of uny apency theresf.
\end{abstract}

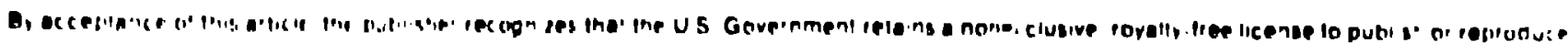

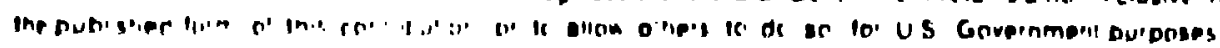


MATERIALS TECHNOLOGY APPLIED TO NUCLEAR ACCELERATOR TARGETS

\author{
BARRY L. BARTHELL \\ MATERIALS SCIENCE AND TECHNOLOGY DIVISION \\ LOS ALAMOS NATIONAL LABORATORY \\ LOS ALAMOS, NM 87545
}

THE CONTINUING REQUFSTS FOR BOTH SHAPED AND FLAT, VERY LOW AREAL DENSITY METAL FOIIS HAVE LED TO THE DEVELOPMENT OF METALLURGICAL QUALITY, HIGH STRENGTH PRODUCTS. THE INTENT OF THIS PAPER IS TO SHOW METHODS OF FORMING STRUCTURES ON VARIOUS SUBSTRATES USING PERIODIC VAPOR INTERRUPTIONS, ALTERNATING ANODES, AND MECHANICAL PEENING TO ALTER OTHERWISE UNACCEPTABLE GRAIN MORPHOLOGY WHICH BOTH LOWERS TENSILE STRENGTH AND CAUSES HIGH STRESSES IN THIN FILMS.

FIGURE I IS A CROSS-SECTION OF SUCH A FOIL, IT SHOWS AN AL/AL $O_{Y} O_{Y}$ LAMALLER STRUCTURE OF - $50 \mathrm{nM}$ THICK AL LAYERS WITH AN INTERFACE OF AL $C_{Y}$ THAT IS ROUGHLY 5-10 ATOMIC PERCENT OXYGEN. THE: XIELD STRENGTH OF THIS FOIL IS APPROXIMATELY 408 MPa, AS COMPARED WITI $22 \mathrm{MPa}$ FOR A FILM DEPOSITED WITH NO OXYGEN. THE STRENGTHENING EFFECT ALSO IS PARTLY DUE TO THE CONTINUOUS SHIFTING OF NUCLEATION SITES AT THE GROWTH PLANE. THE PROPERTIES OF THIS FOIL WERE WELL PREDICTED AND FOLLOW THE HALL-I'ETCH RELATION FOR YIELD STRENGTHS VERSUS LAYER ISPACINGS AS SHOWN BY R.W. SPRINGER, D.S. CATLETT, THIN SOLID FILMS, 54 (1978) 197-205. THERE IS LITTLE DOUBT THAT MANY OTHER MATERIALS COULD BE FORMED 
IN THIS MANNER, HOWEVER, ALUMINUM HAS BEEN, BY FAR, THE MOST REQUESTED MATERIAL, AND LITTLE DEVELOPMENT HAS BEEN DONE WITH ANYTHING ELSE. THE HIGH YIELD STRENGTH OF THESE FOIIS ALIOW VERY THIN SHAPED STRUCTURES TO BE PRODUCED, SUCH AS THE ONE SHOWN IN FIGURE 2. THE FOIL IS $2 \mathrm{CM}$ HIGH, WITH A 2 CM RADIUS. THE THICKNESS IS $0.2 \mu \mathrm{m}\left(54 \mu \mathrm{GM} / \mathrm{CM}^{2}\right)$. THESE FOILS ARE USED BY THE AIR FORCE WEAPONS LABORATORY IN THE SHIVA STAR ACCELERATOR IN LARGE RADII, THE SANDIA NATIONAL IABORATORY IN THE PROTO II ACCELERATOR SMALLER RADII AND BY LOS ALAMOS IN AN EXPLOSIVELY DRIVEN TRAILMASTER, PULSED POWER DEVICE. THE PROCESS FOR MAKING THEM IS DESCRIBED BY D. DUCHANE AND B. BARTHELL, THIN SOLID FILMS, 107 (1983) 373-378, AND IN US PAT. NO. 4,481,999 AND CA PAT. NO. 1,196,469. GOLD FOILS, FIGURE 3, CAN BE PRODUCED WITH THINNER CROSS-SECTIONS $(0.1 \mu \mathrm{M})$ WITHOUT LAMINATION. TYESE FOILS ARE ALL FORHED ON A POLYVINYL ALCOHOL SUBSTRATE (FIGURE 4) WHICH IS WATER SULUBLE, AND IS SUBSEQUENTLY REMOVED, LEAVING AN UNBA.CKED FOIL.

EXTREMELY SMDOTH, DEFECT FREE SUBSTRATES ARE VITAL TO THE MANUFACT'JRE OF THESE TOILS. A PROCESS FOR SMOOTHING POLY METHYL METHACRYLATE (LUCITE) (FIGURE 5; IS DESCRIBED BY D. DUCHANE, J. VAC. SCI. TECHNOL. 18 (3) APRIL 2981, AND IN U.S. PAT. NO. 4,376,751 POIYMER SUBSTRATES SMOOTHED BY THIS TECHNIQUE WERE USED TO FORM SMALL TUBES (SODA STRAWS) OF ALUMINUM THAT INCORPORATE $A$ 20OA IAYER OF COPPER INSIDE (FIGURE 6). THE NEEN TO MAKE THESE FOILS BIMETALLIC PRECLUDED THE S'TANDARD METHOD OF FORMING THE SUBSTRATE FOR THE PRODUCTION OF SMALL-DIAMETER, TUBULAR ALUMINUM FOILS, NORMALLY A COPPER FOIL IS DEPCSITED ON GLASS TUBING AND 
THE GLASS IS DISSOLVED IN HYDROFLUORIC ACID LEAVING A SUPER SMOOTH COPPER SUBSTRATE. THE COPPER IS COATED WITH ALUMINUM AND THEN SUBSEQUENTLY SELECTIVELY LEACHED AWAY ITSELF.

FLAT ALUMINUM SHAPES ARE FORMED ON MANDRELS PRODUCED USING SINGLE POINT DIAMOND KNIFE MACHINING SUCH AS THESE BEAM STRIPPERS (PAC MANS) AND ALIGNMENT RIBBONS (HARPS) (FIGURE 7) AND SIEVES (FIGURE 8) USED IN IOS ALAMOS MESON ACCELERATOR. THE SURFACES OF ALI THESE FLAT MANDRELS ARE COATED WITH $250 A$ OF CESIUM IODIDE WHICH IS WATER SOLUBLE AND ALLOWS THE SHAPED FOILS TO BE FLOATED OFF IN WATER. ANOTHER METHOD MAKES USE OF PHOTOLITHIOGRAPHY TO FORM THE MANDREL (FIGURE 9) BY ETCHING COMPLEX FLAI FORMS SUCH AS THIS $97.5 \%$ TRANSPARENT SUPPORT GRID, $5 \mu \mathrm{M}$ THICK, USED AS THE SUPPORT FOR ULTRATHIN STRIPPER FOILS OF CARBON OR ALUMINUM. FIGURE 10 SHOWS A BEAM COLLIMATING SLIT ARRAY FOIL. THESE. DEVELOPMENTAL STRUCTURES SUCH AS A 60OA FOIL ON A I CM SQUARE, - $97 \%$ TRANSPARENT MESH (FIGURE 11) AND A 600A ALUMINUM FOIL ON AN 87\% TRANSPARENT MESH (FIGURE 12) WILL BE USED AS NEIJTRALIZER FOILS FOR NEUTRAL PARTICLE BEAM ACCELERATORS AT LOS ALAMOS AND AT THE WHITE SANDS MISSILE RANGE. THESE THIN FILMS ARE BEING DEVELOPED BY G. REEVES AND WILL ULTIMATELY BE $250 \AA$ TO 400 A THICK AND 1 METER IN DIAMETER.

IN OUR EFFORTS TO FABRICATE LASER ACCELERATOR TARGETS, A METAL COATED FOPM STRUCTURE WAS DEVELOPED BY DEPOSITING A LAYER OF POLYVINYL ALCOHOL OR HYDROXYPROPYL CELLULOSE ON A LOW DENSITY, OPEN CELL, FOI,YMETHLY PENTENE FOAM TO FORM AN EXTREMELY SMOOTH, CONTINUOUS FILM. THIS WAS COATED WITH $5 \mu \mathrm{M}$ OF ALUMINUM TO PRODUCE THE SURFACE SHOWN IN FIGURE 14. THIS PROCESS IS 
DESCRIBED BY B. BARTHELL AND D. DUCHANE, J. VAC. SCI. TECHNOL 20 (4) APRII, 1982 AND IN US PAT. NO. 4,555,313.

THIN $\left(60 \mu \mathrm{GM} / \mathrm{CM}^{2}\right.$ ) LARGE ( 1 METER BY $\left.30 \mathrm{CM}\right)$ POLYMER FIIMS WERE PRODUCED BY DIPPING A POLISHED STAINLESS STEEL, CYIINDRICAL FORMING RING INTO A SOLUTION OF POLYVINYL ALCOHOL, DRYING, AND THEN DIPPING THE RING INTO A DILUTE SOLUTION OF POLYVINYL FORMAL (FORNIAR) AND STRIPPING THE COMPOSITE FILM FROM THE RING WHEN DR.Y. THE BILAYER SHEET WAS THEN MOUNTED ON A FRAME TO FORM A IARGE PELLICLE. AFTER THE FILM WAS IN PLACE THE WATER SOLUBLE P.V.A. WAS WASHED AWAY, LEAVING THE ULTRATHIN FORMVAR NINDOW. THE PROCESS IS DESCRIBED IN US PAT. NO. 4,448,662.

A HIGH PRESSURE TRITIUM TARGET (FIGURE 15) WAS MANUFACTURED ELECTROCHEMICALLY BY FIRST COATING AN ALUMINUM MANDREL WITH COPPER AND TIN IEAD SOLDER, ALONG WITH THE TARGET END CAPS AND JOINING THEM TOGETHER THERMALLY (FIGURE 16) AND COATING THE ASSEMBLY WITH NICKEL COBALT I25M THICK (FIGURE 17). THE ALUMINUM MANDREL WAS REMOVED AS DESCRIBED BY P. BALO, AND R. BRAMLETT IN LOS ALAMOS UNCLASSIFIED REPORT, LA-CP-86-26. THE YIELD STRENGTHS WERE NOMINALLY 1161 MPA U.T.S. WERE 1901 MPA.

FIGURE 16 SHOWS THE LAMALLER STRUCTURE FORMED BY THF NICKEL COBALT BATH WHICH USES TWO SEPARATE ANODES. THE PLATED PART IS ROTATED PAST EACH ONE FORMING THE LAYERED STRUCTURE.

CHEMICAL VAPOR DEPOSITION (PVD) IN A FLUID BED (FIGURE 17) IS USED TO FORM TUNGSTEN EYLIJIDERS ON MOLYBDENUM MANDRELS WHICH ARE SELECTIVELY DISSOLVED AWAY. BECAUSE OF THE PEENING ACTION OF THE BED THE GRAIN SIZE IS MARKEDLY REDUCED (FIGURE 18) AS SHOWN IN COMPARISON WITH C.V.D. DONE WITHOUT A FLUIDIZED BED. FIGURE 
19 SHOWS A CROSS-SECTION OF THIS FINE STRUCTURE. FIGURE 20 IS A SCANNING ELECTRON MICROGRAPH AGAIN SHOWING THE STRUCTURE COMPARISON. THE PRODUCT IN THIS CASE (FIGURE 21) IS A FREE CYLINDRICAL FOIL WHICH HAS BEEN MADE WITH A WALL THICKNESS OF $0.6 \mu \mathrm{M}$ AND $>0.1 \mu \mathrm{M}$ VARIATION AS SHOWN BY D. CARKOLL, AND W. MCCREARY, J. VAC. SCI. TECHNOL. 20 (4) APRIL 1982.

IN SUMMARY THE THREE TECHNOLOGIES, PHYSICAL VAPOR DEPOSITION, ELECTROCHEMISTRY, AND CHEMICAL VAPOR DEPOSITION AND THEIR THIN FIIM PRODUCTS CAN BENEFIT FROM THE USE OF LAMINATE TECHNOLOGY AND CONTROL OF GRAIN STRUCTURE MORPHOLOGY THROUGH THE USE OF MATERIALS RESEARCH AND TECHNOLOGY. 


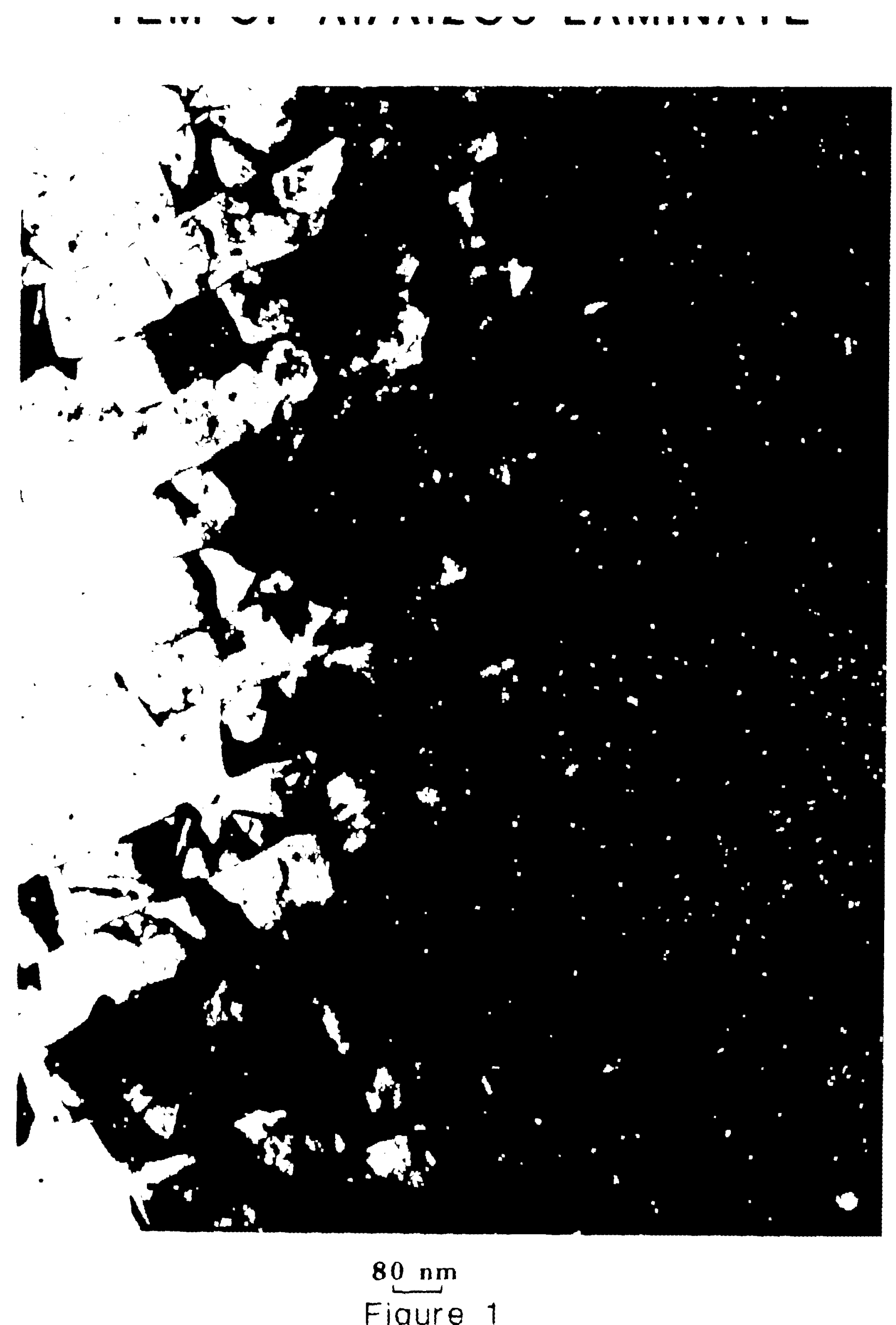




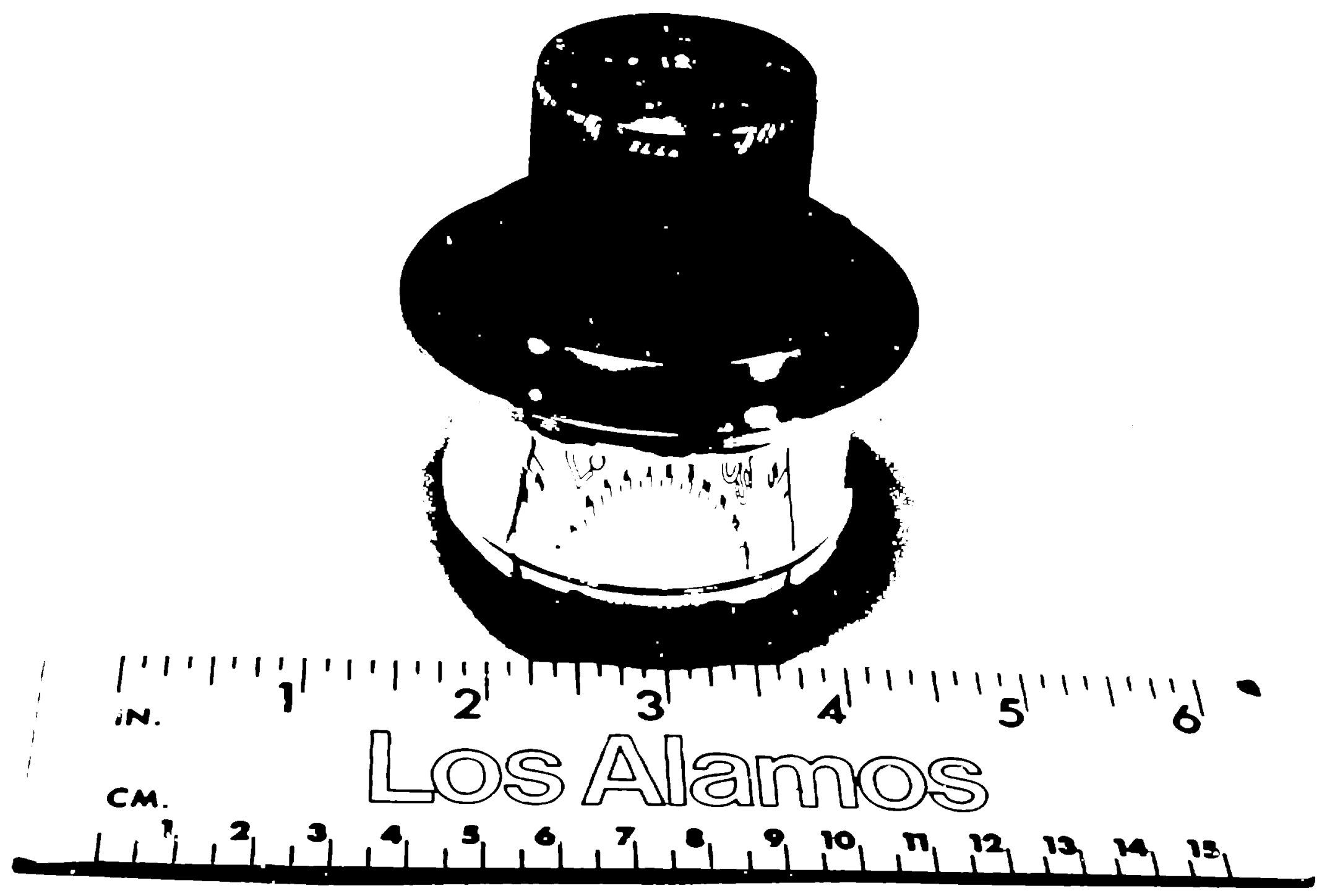

Figure 2 


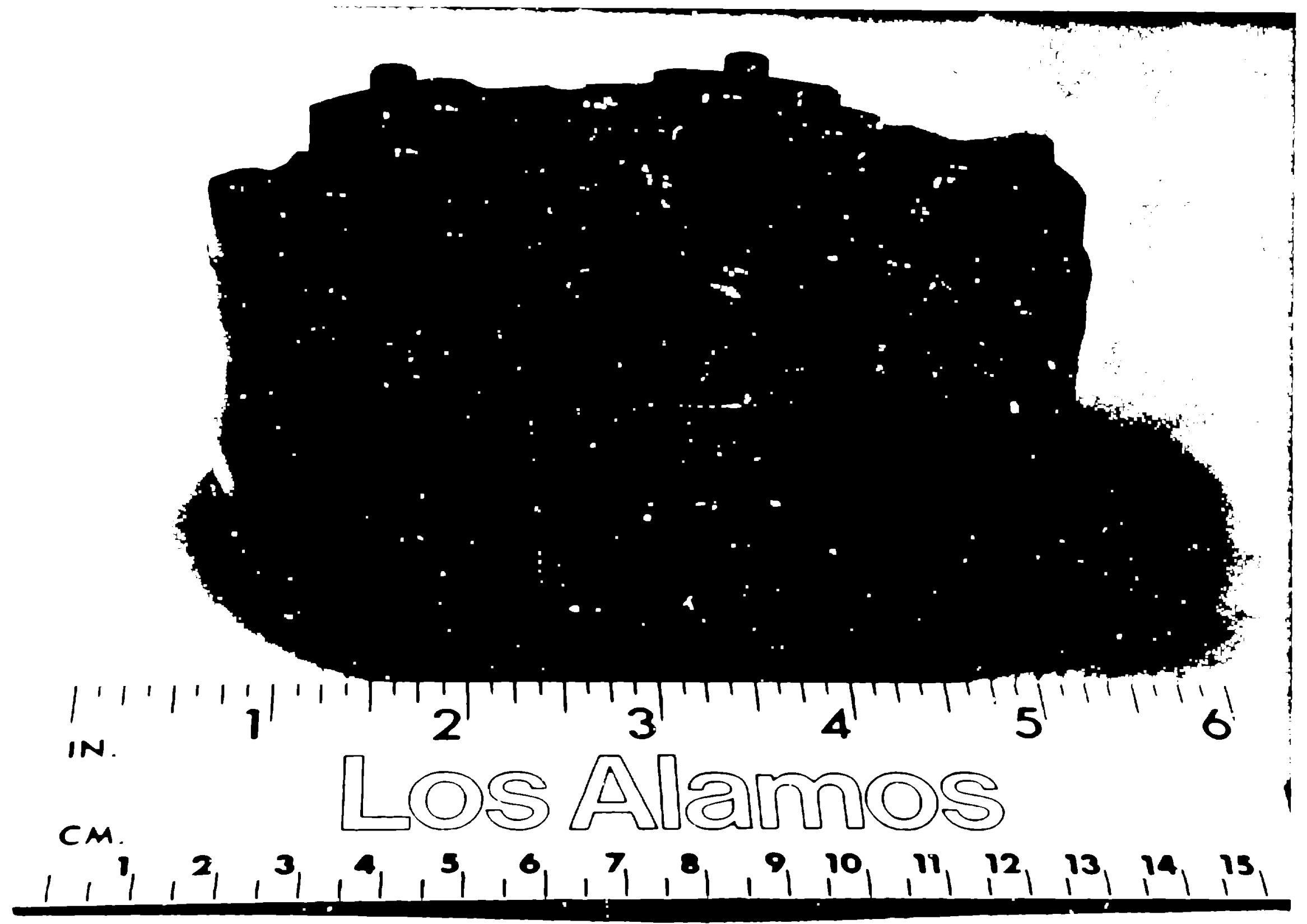

Figure 3 


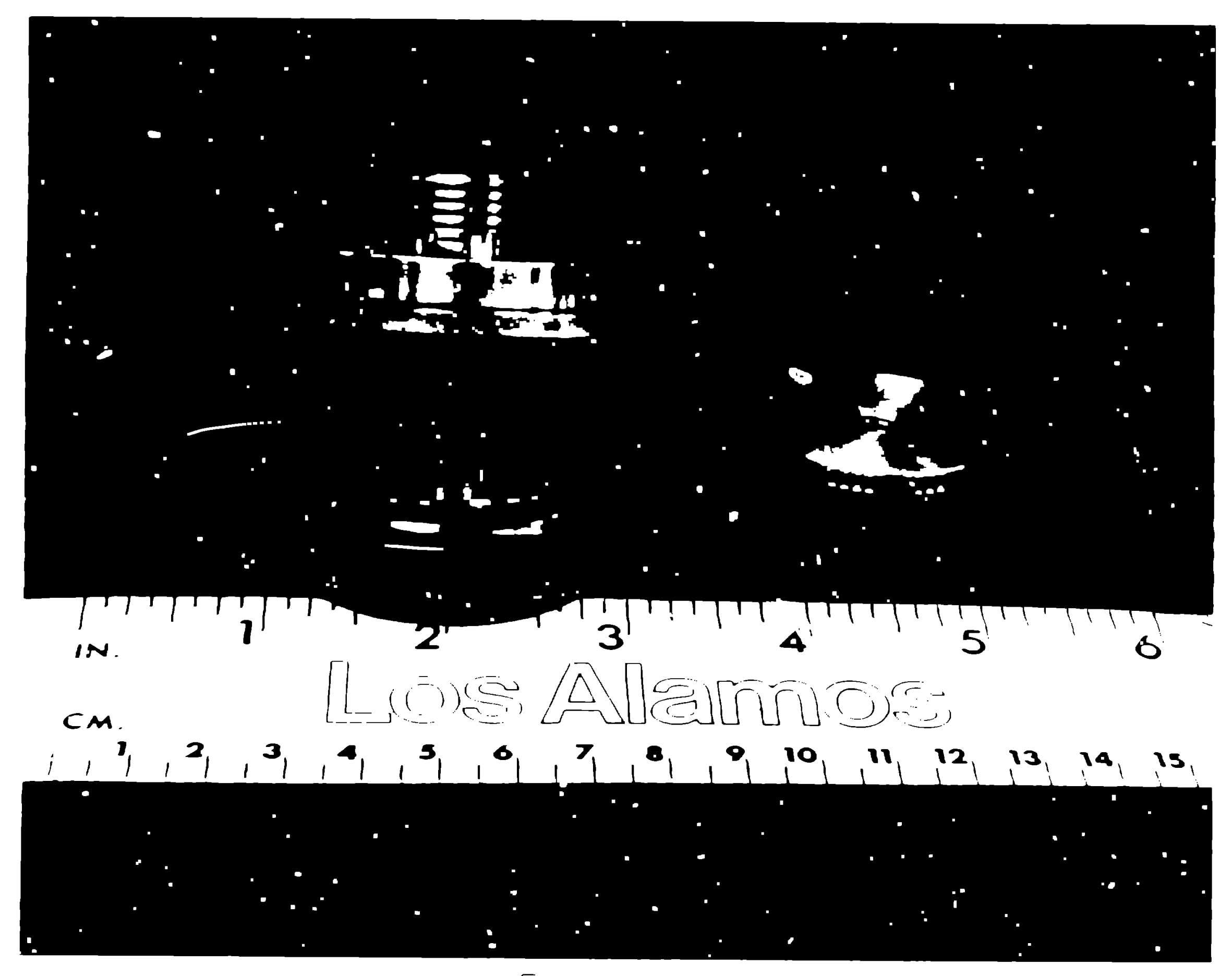

Figure 4 


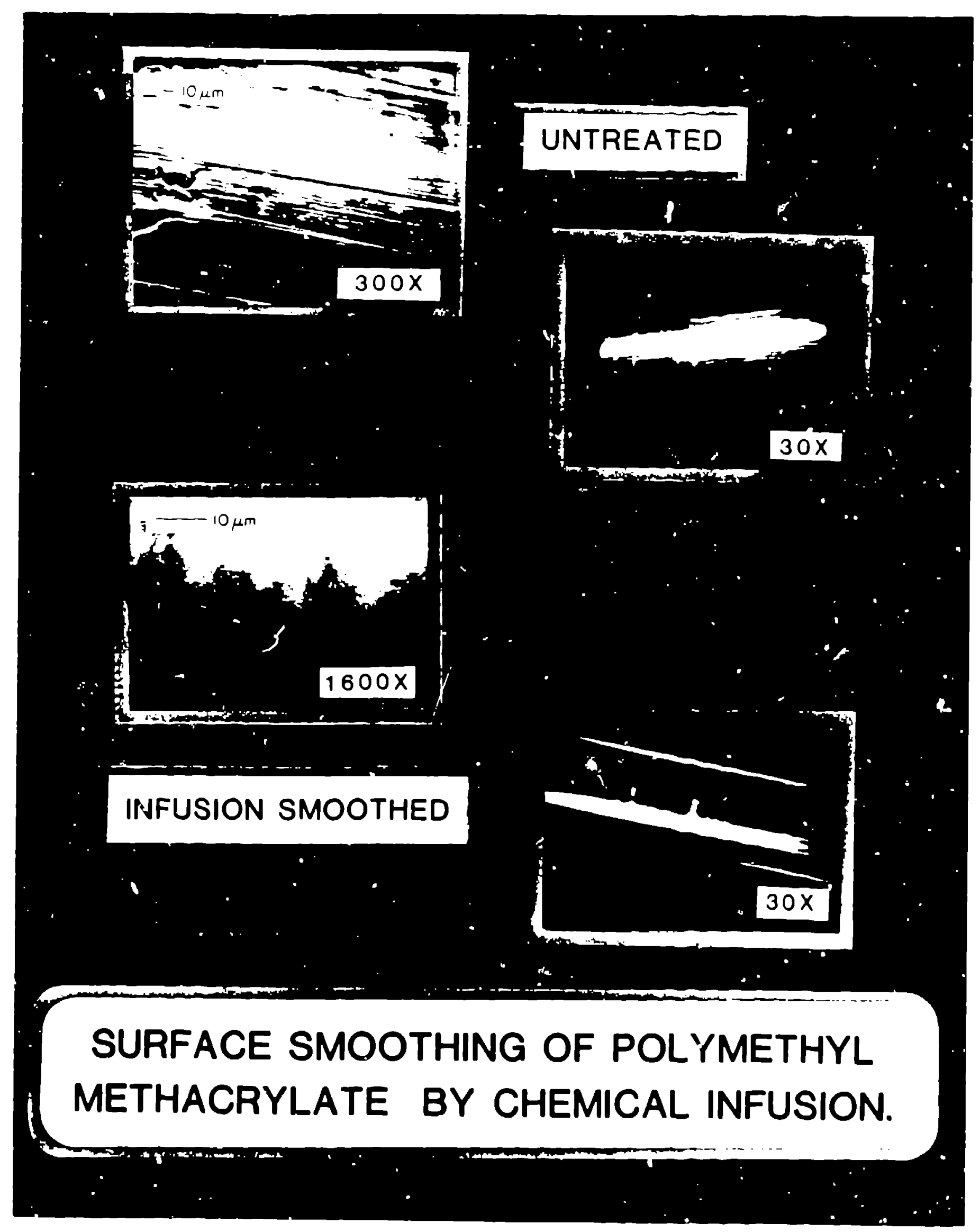

Figure 5 

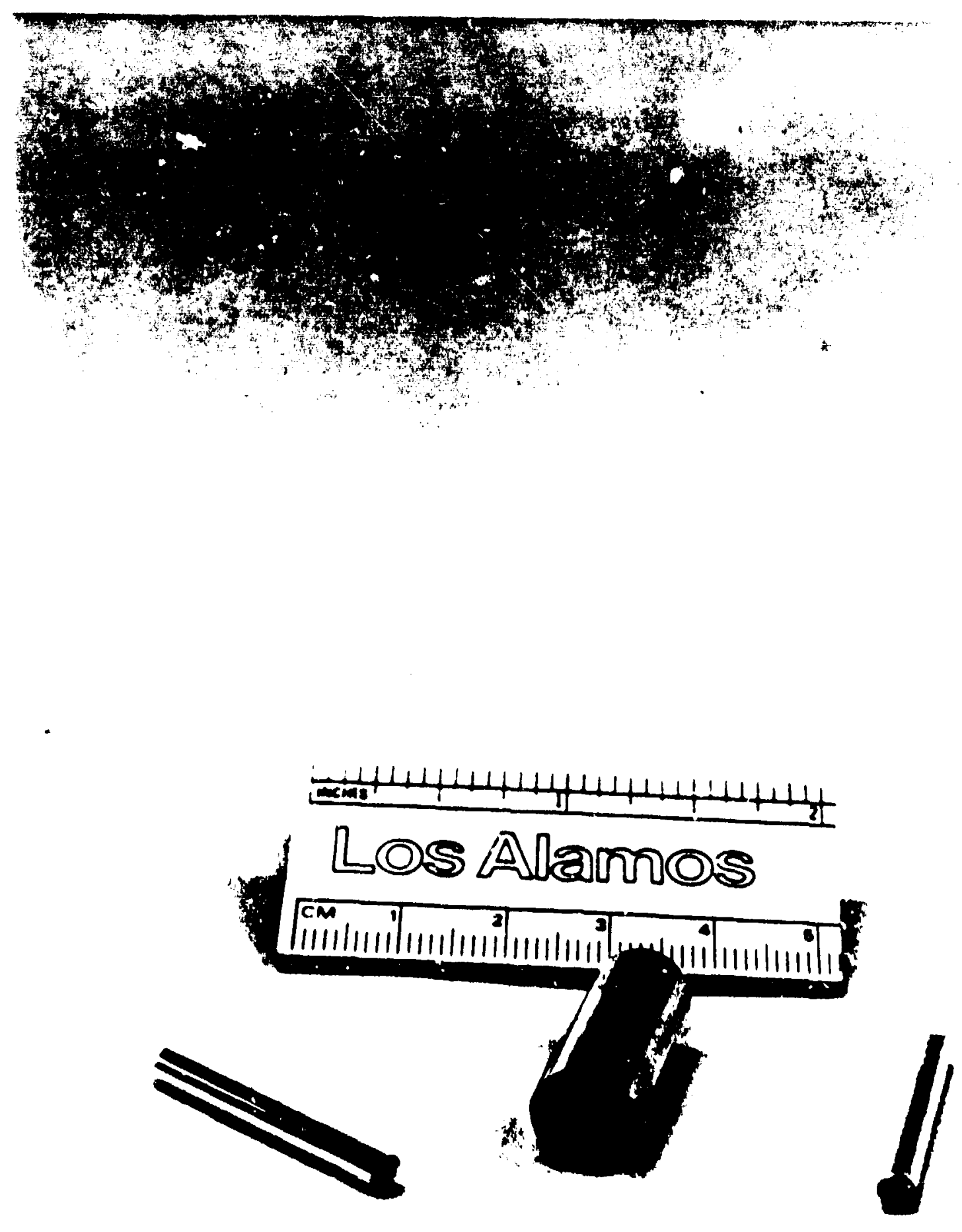

Figure 6 


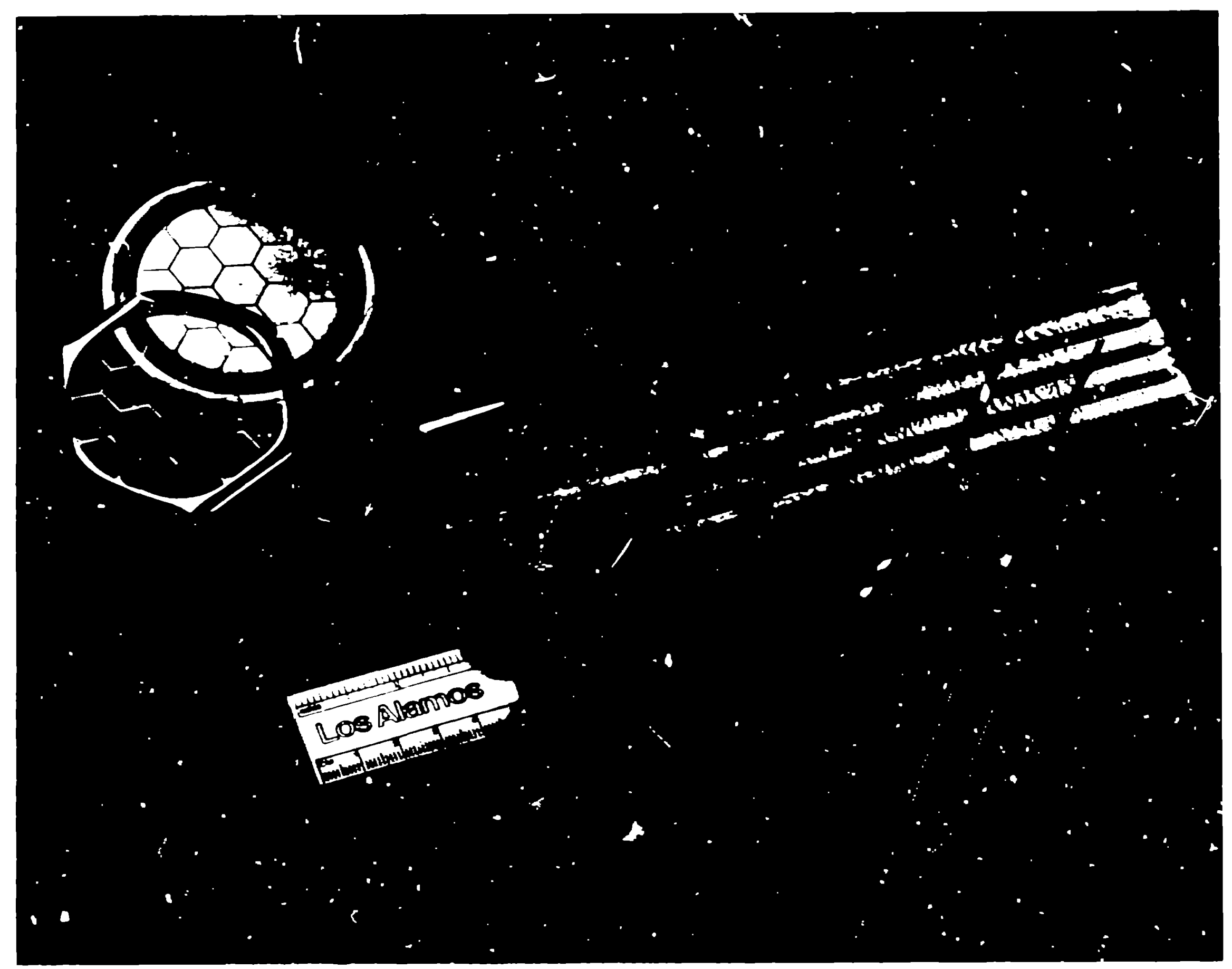

\section{Fiaure 7}




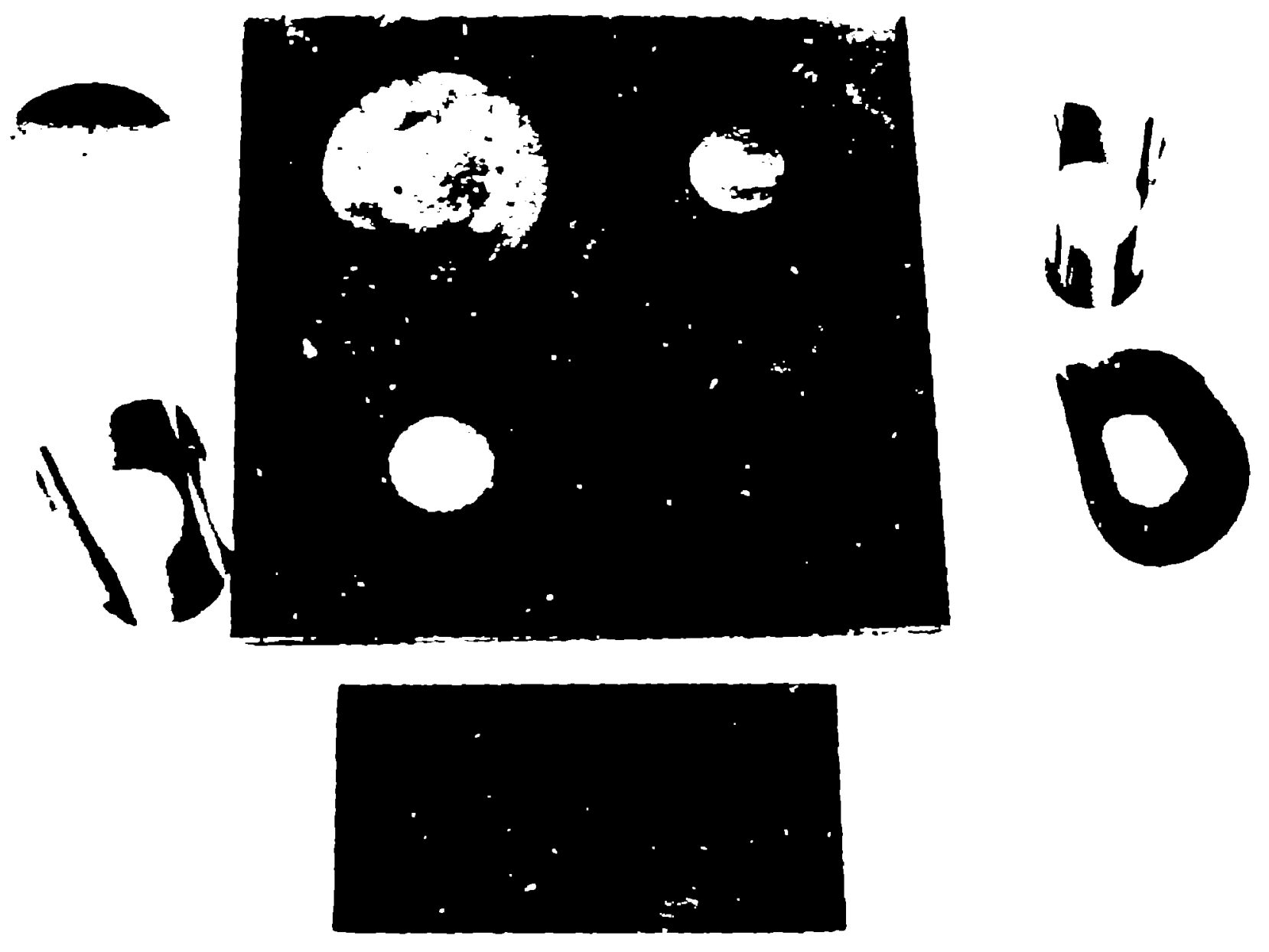

Figure 8 


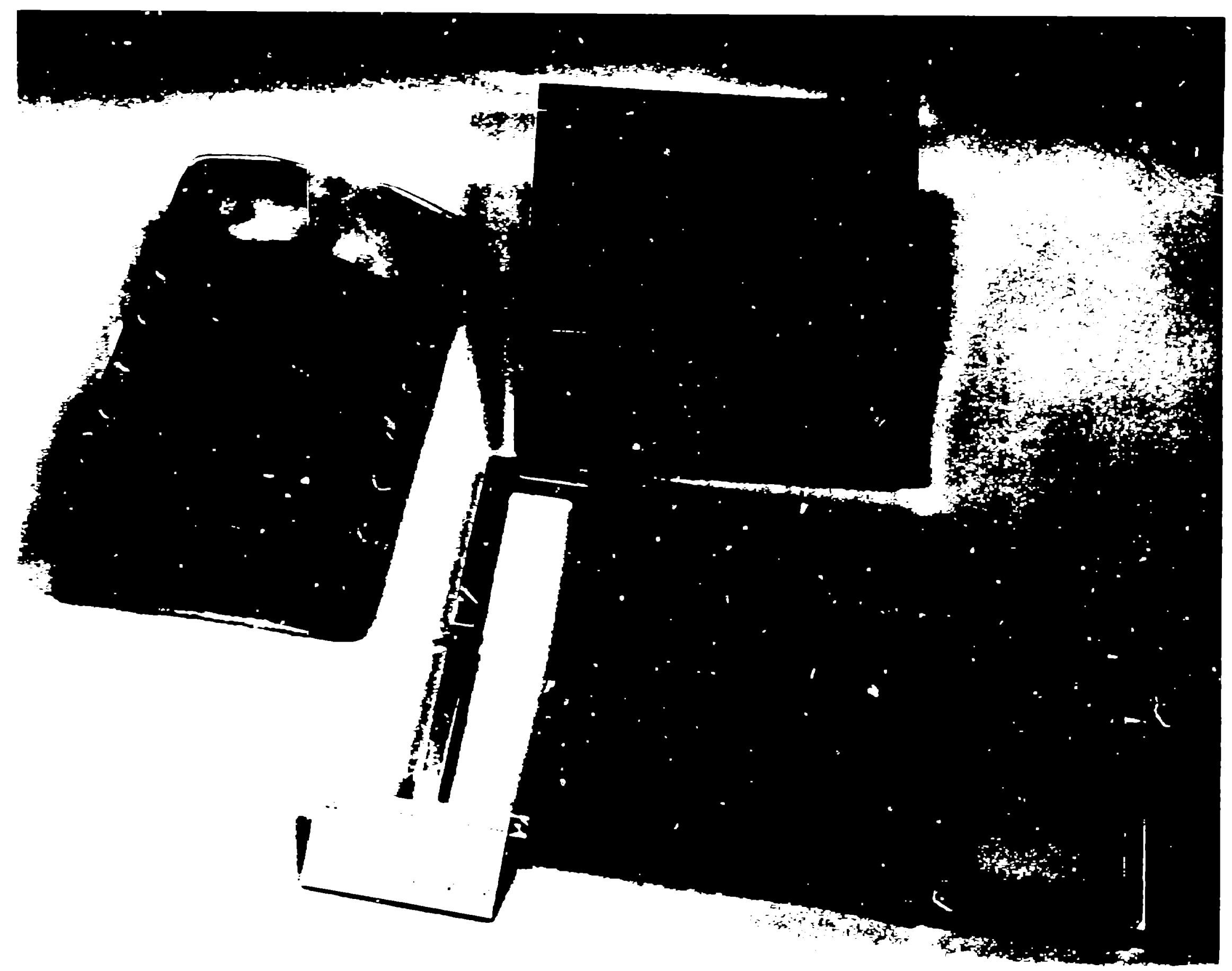

Figure 9 


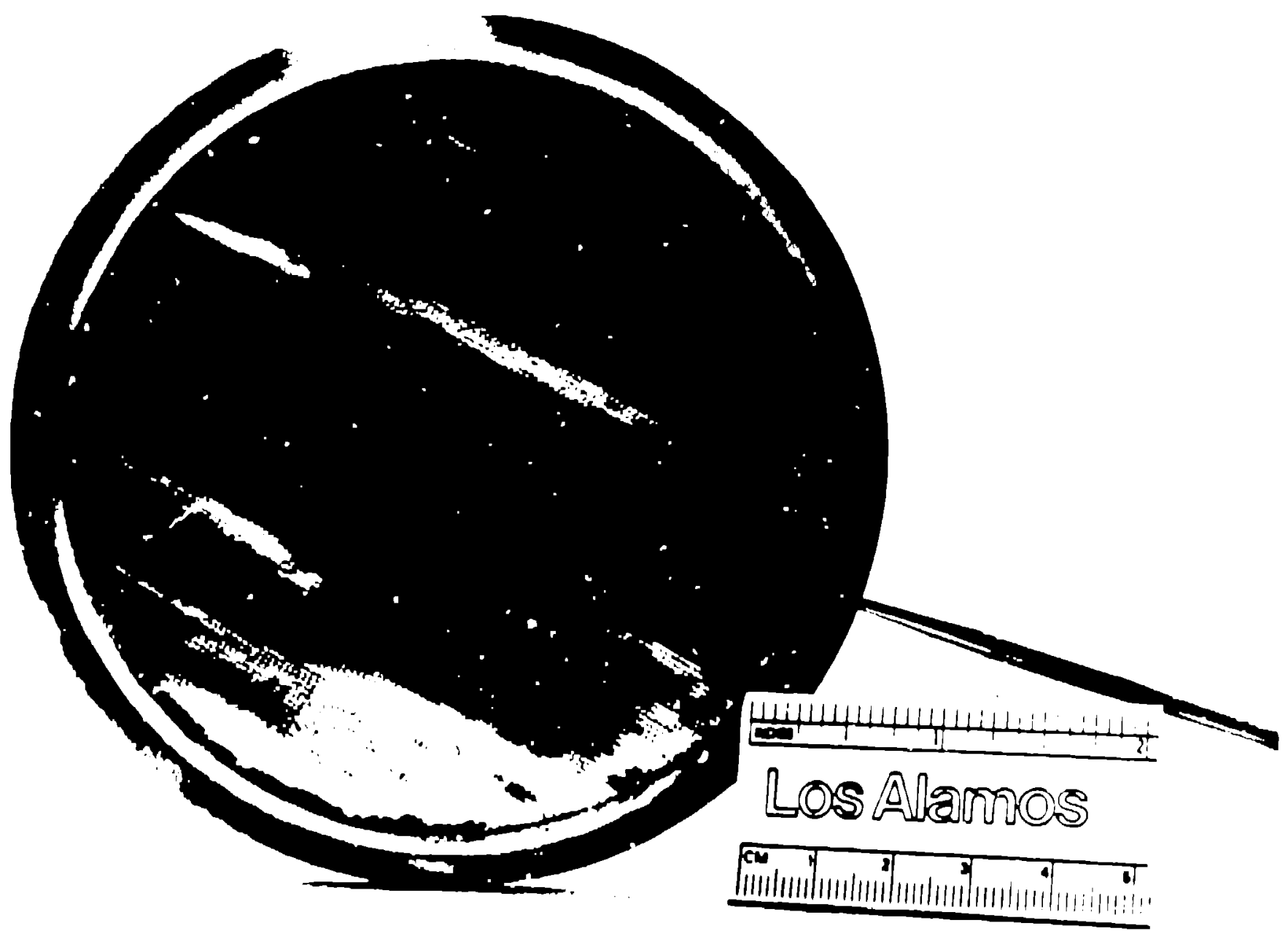

Figure 10 


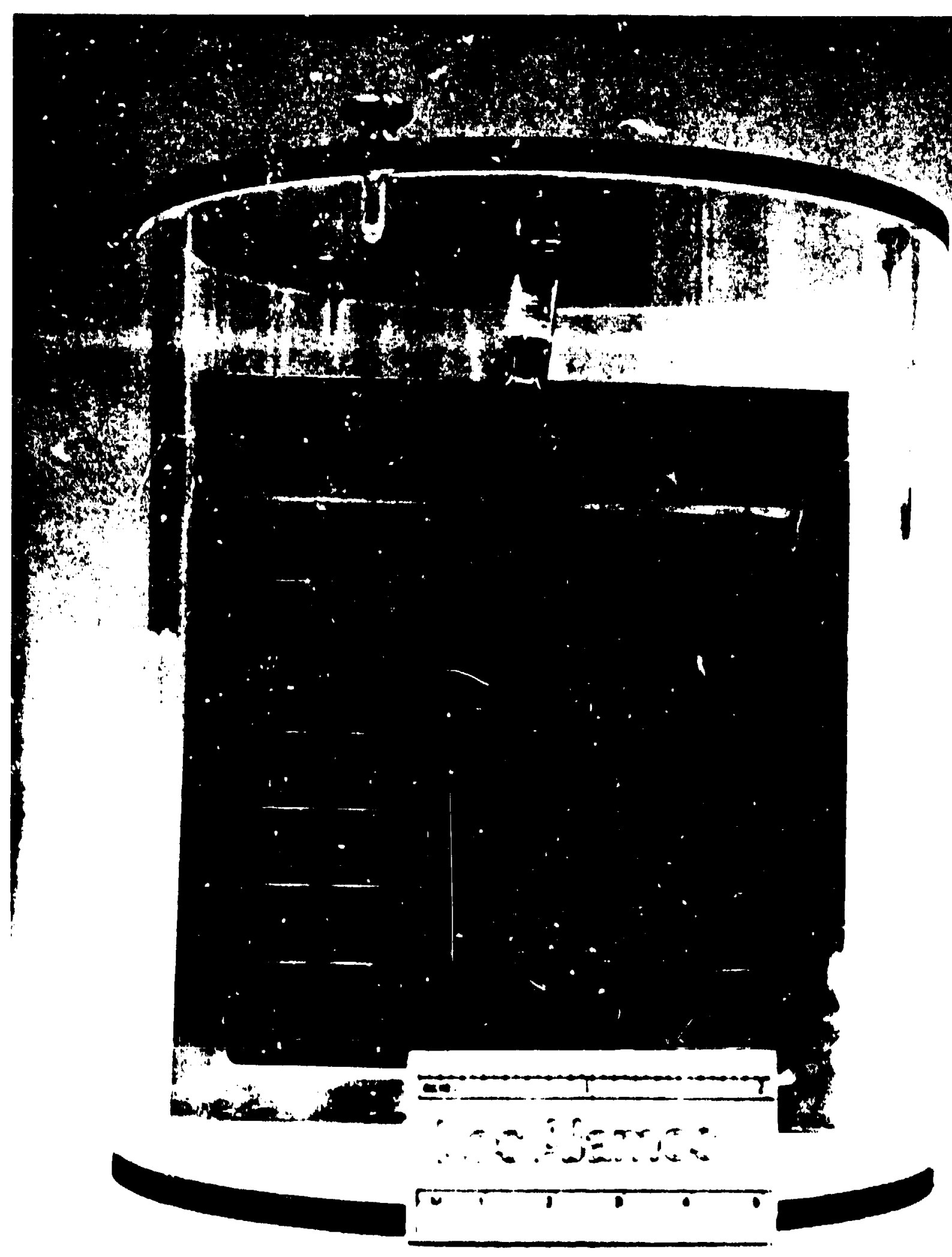

Figure 11 


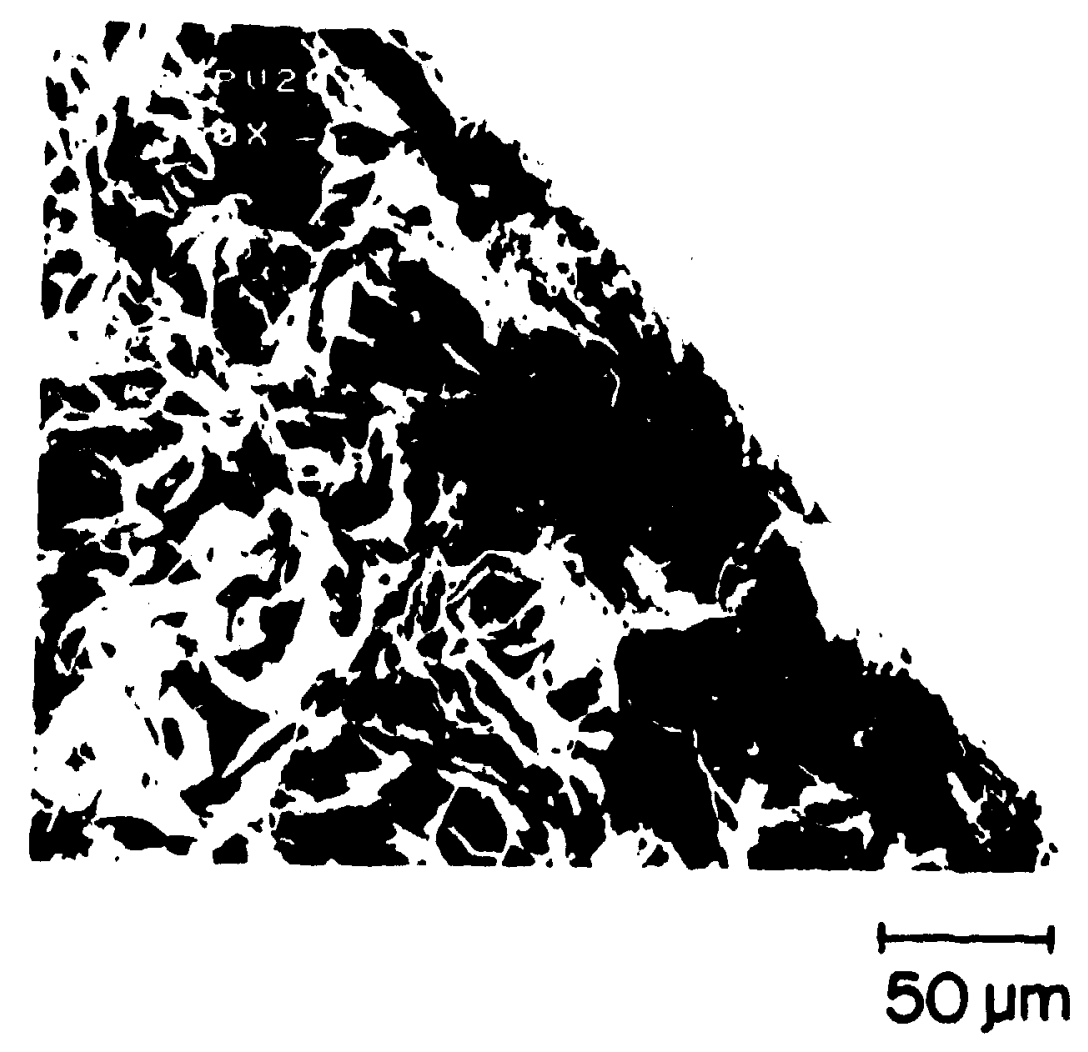

PVA

On

TPX

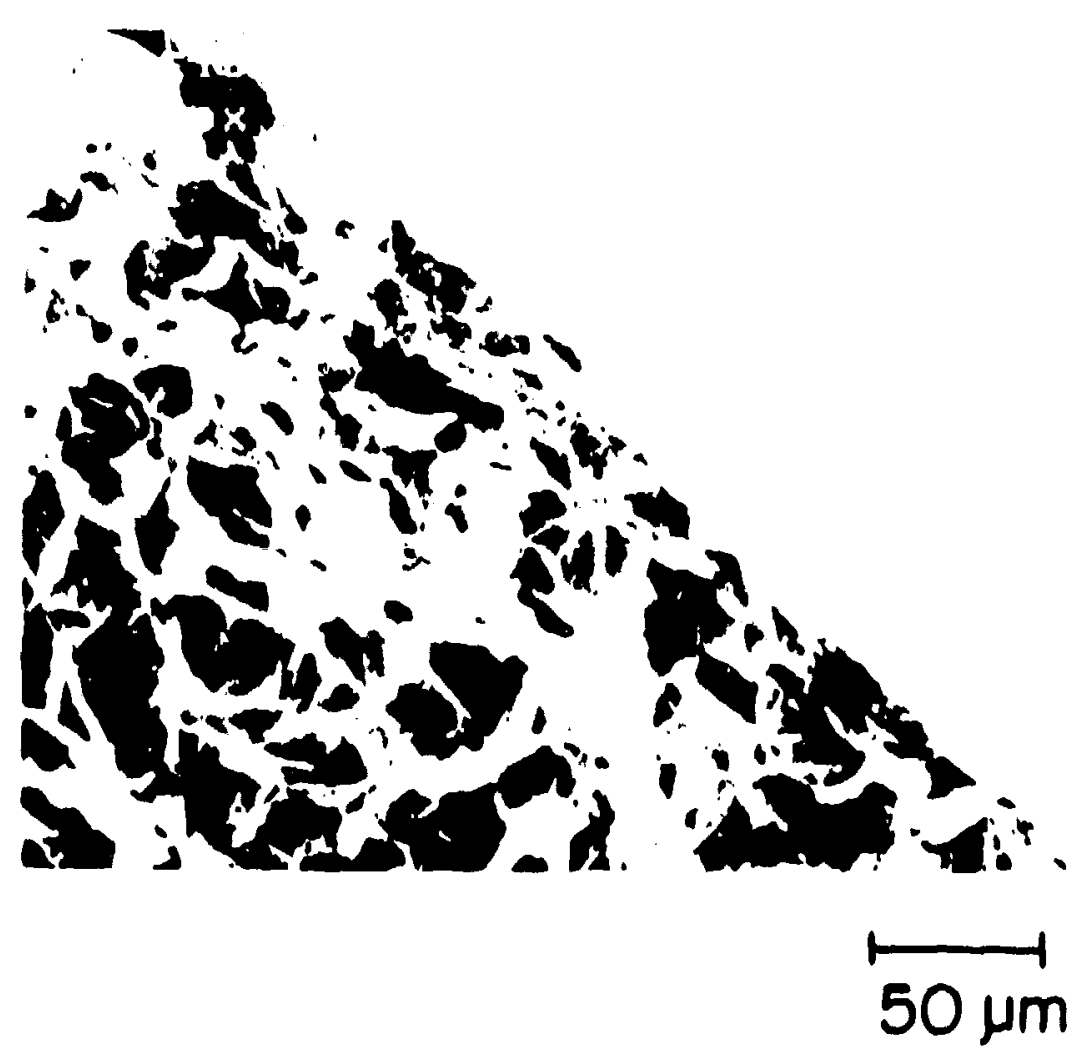

Klucel

On

TPX

Figure 12 


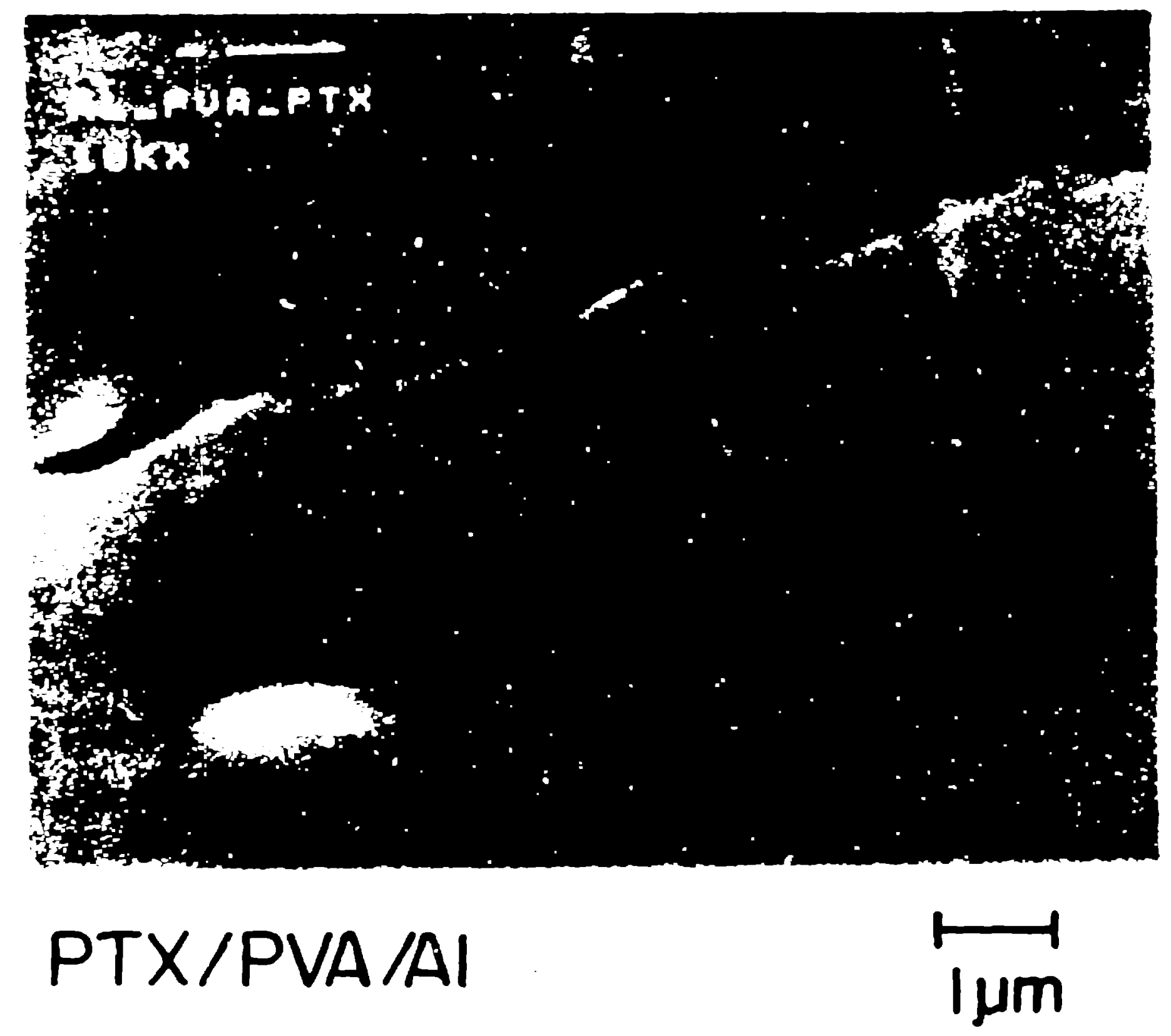

Figure 13 


$$
5
$$




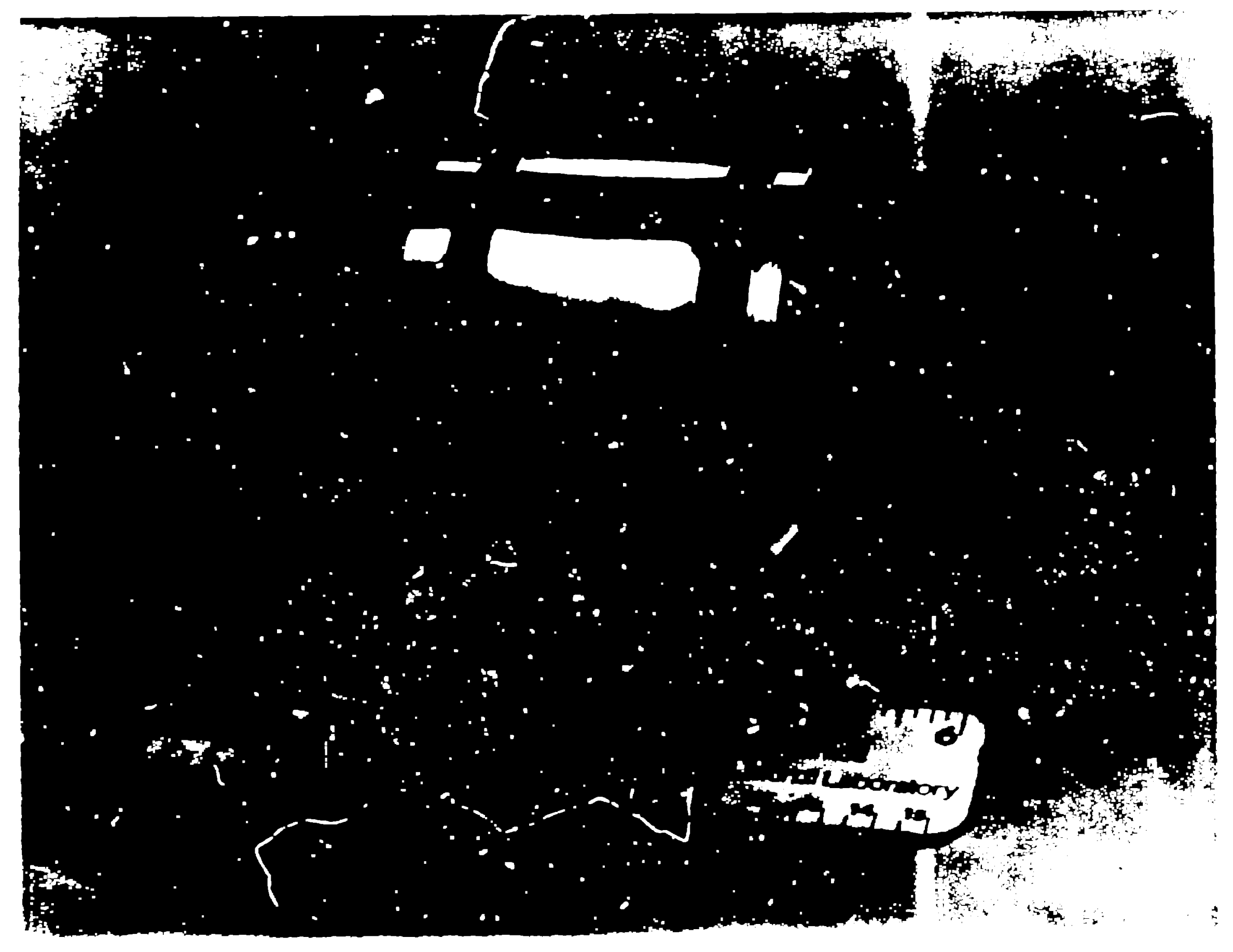

Finaro 15 



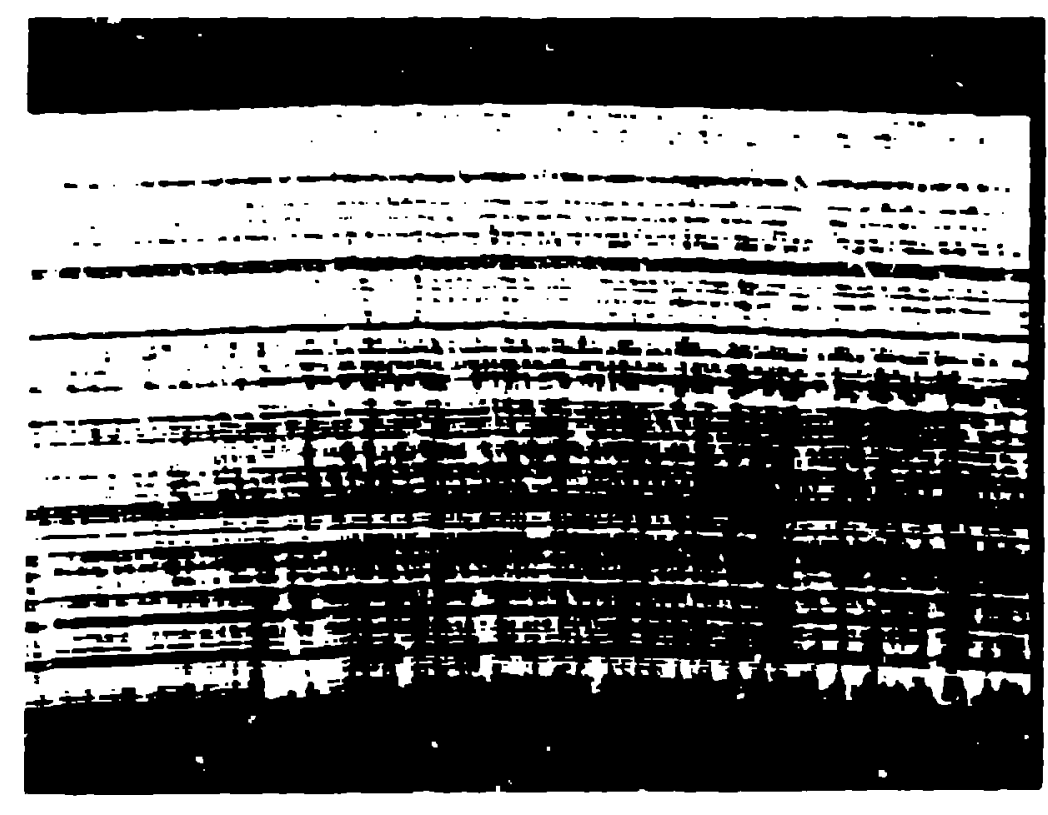

Figure 17 


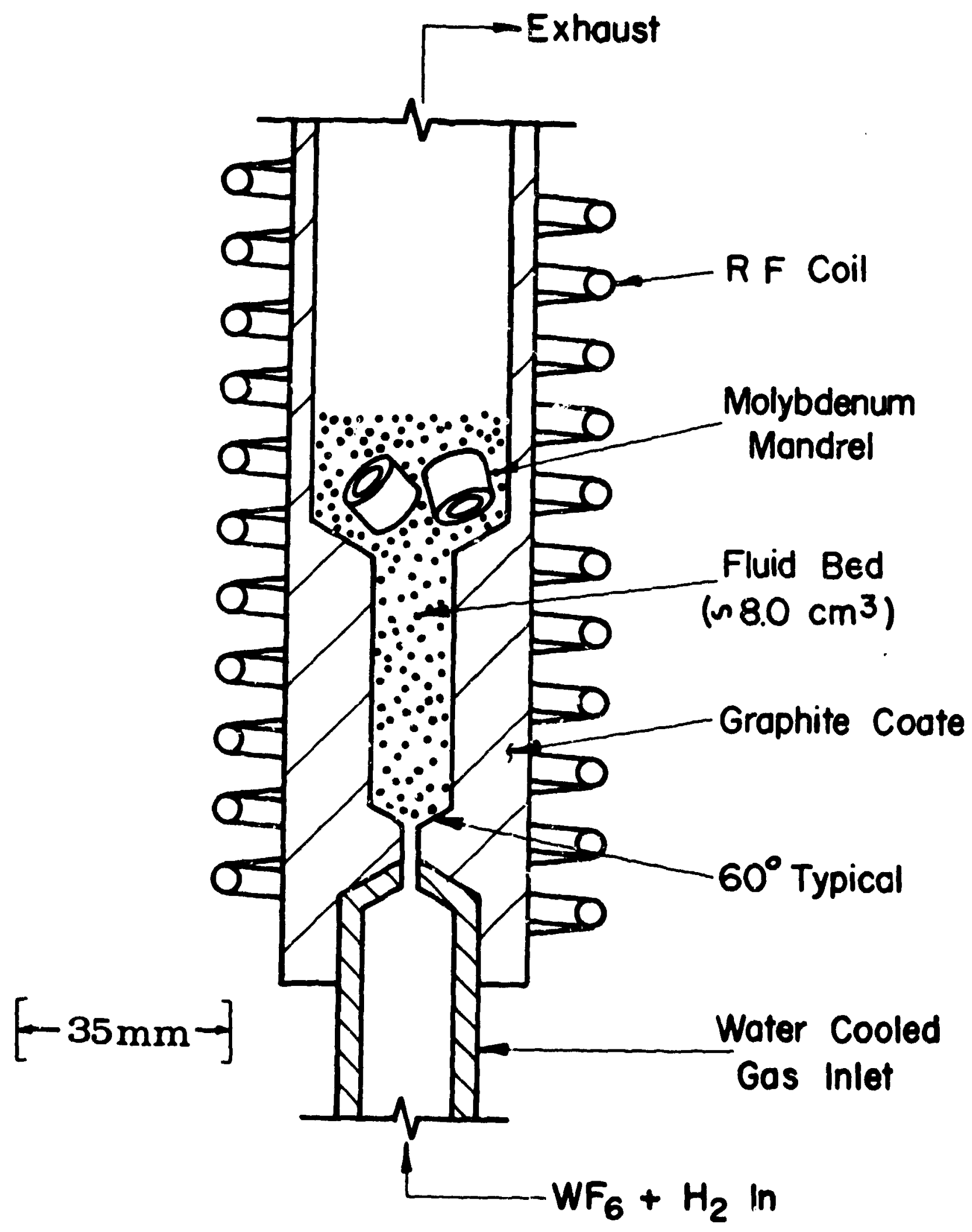

Figure 18 


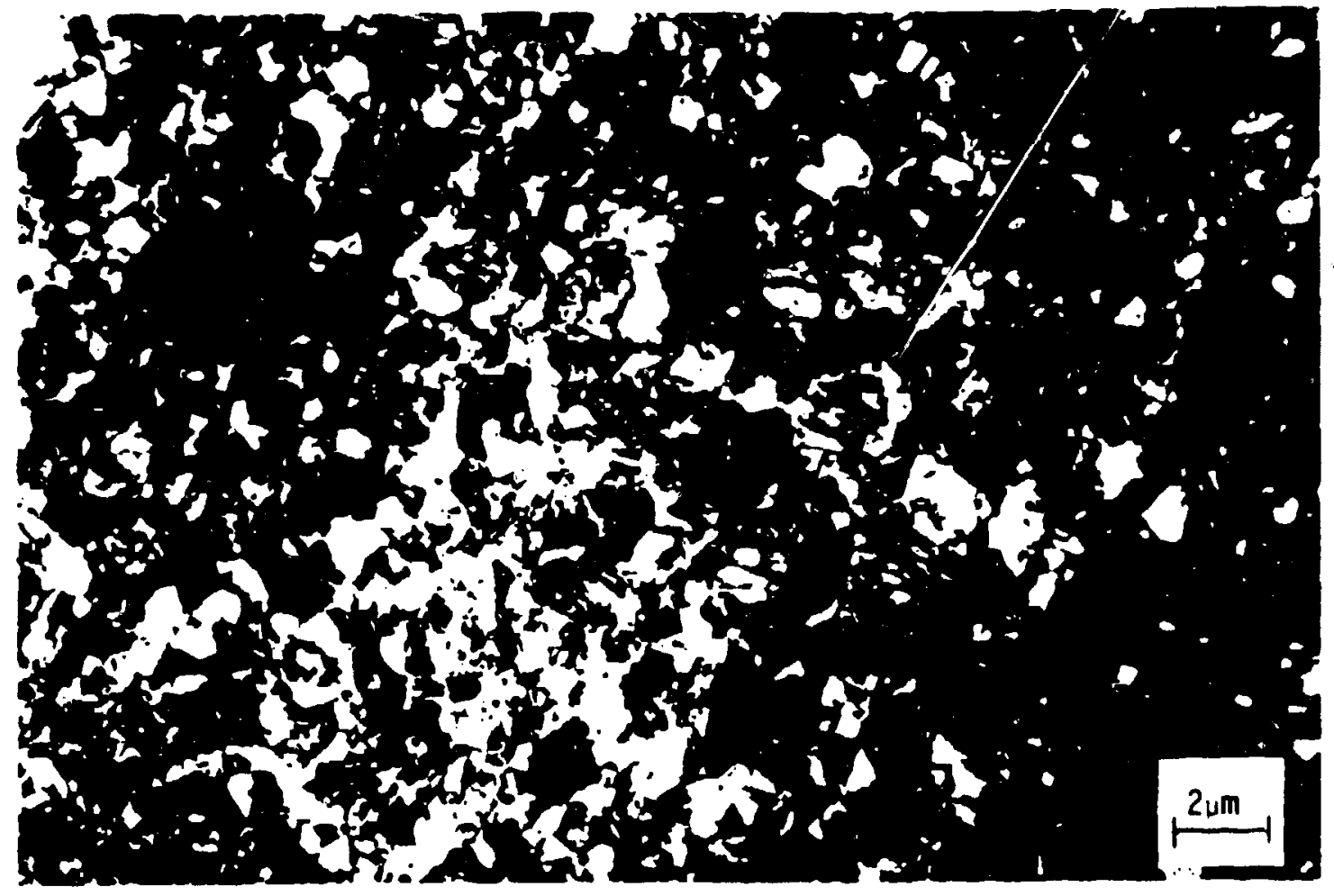

A. TEM OF A 2-pN TUNGSTEN FILM

$5.4 k x$

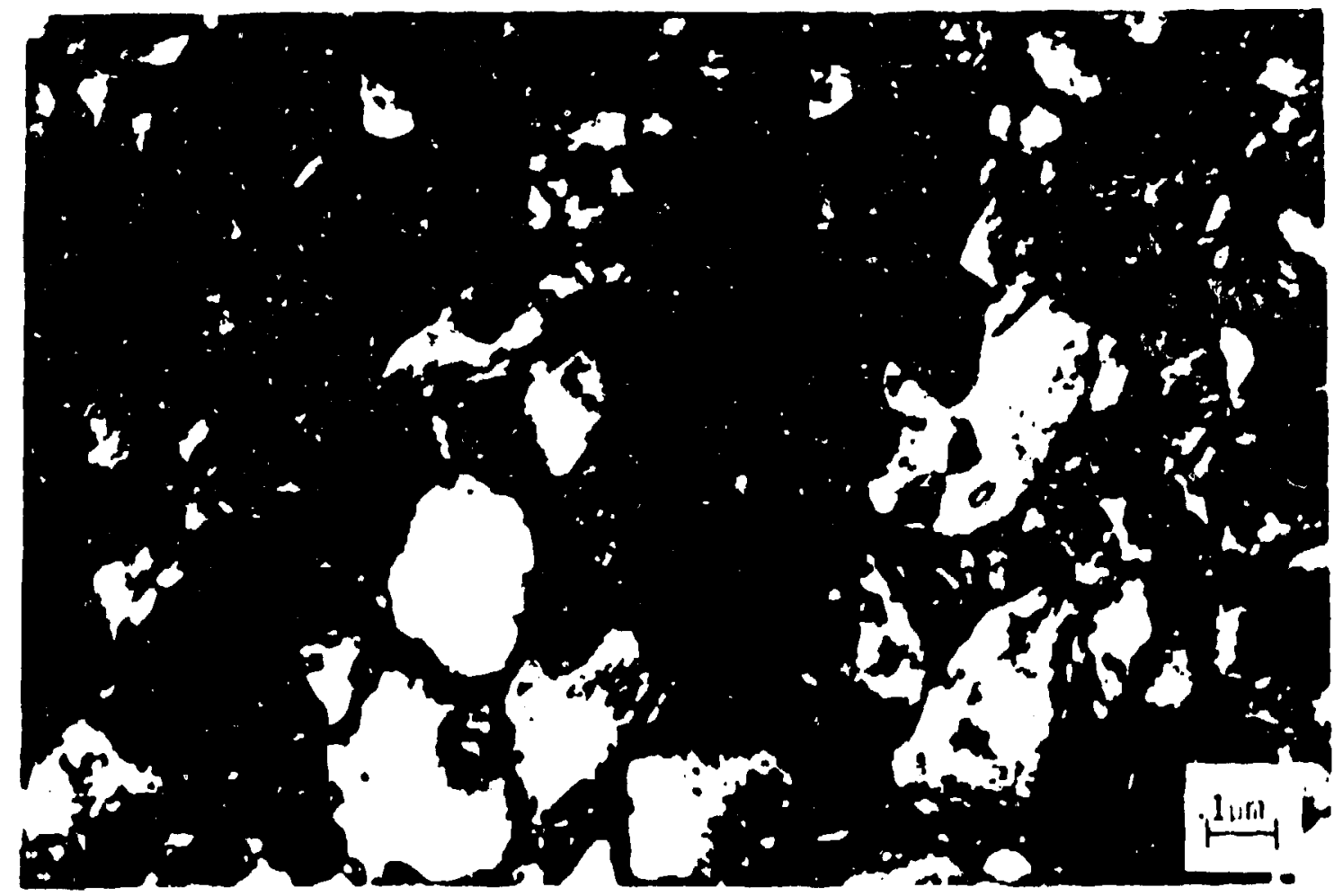

B. TEM OF A 2-p TUNGSTEN FILM

$84 k x$

Figure 19 

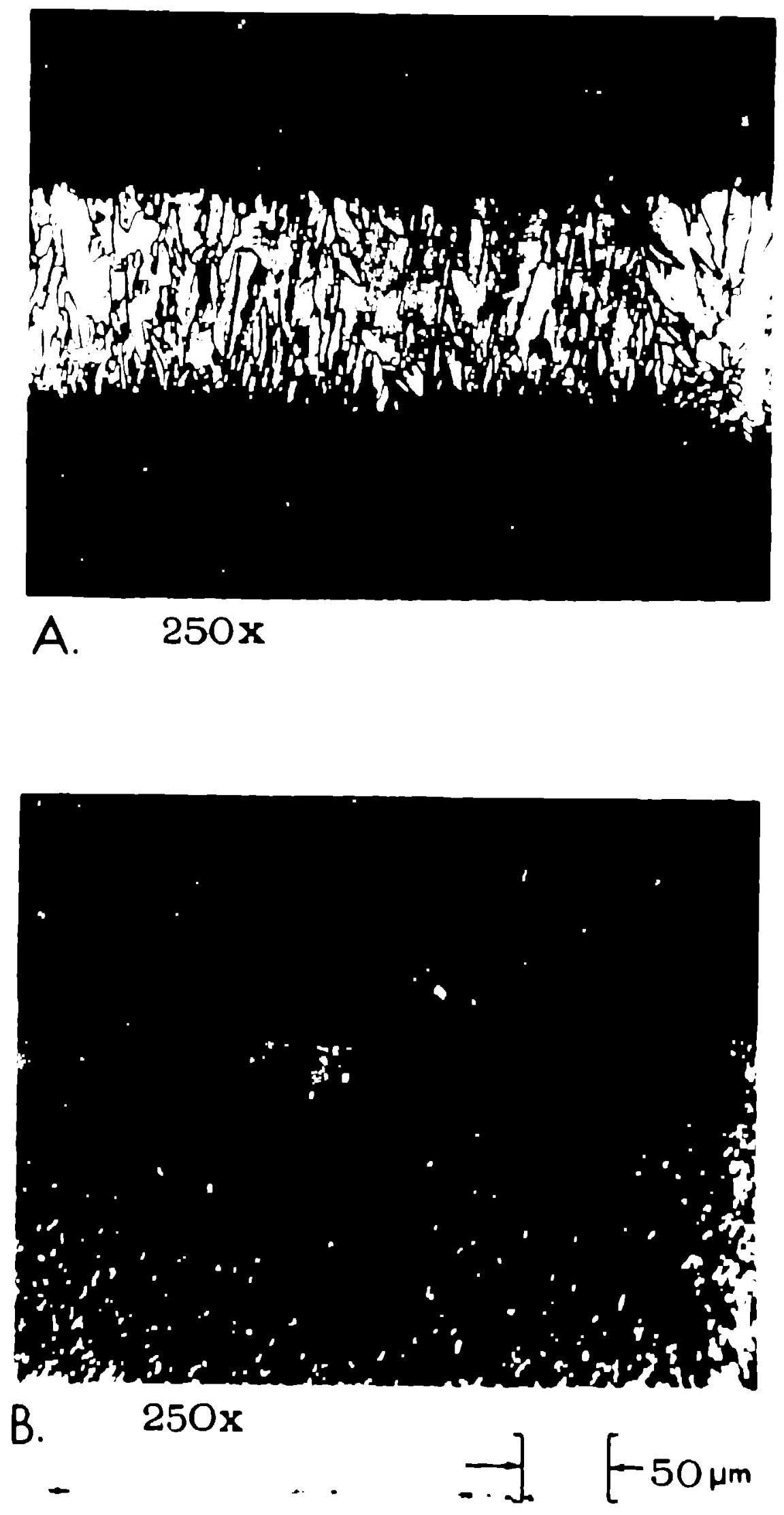

Figure 20 

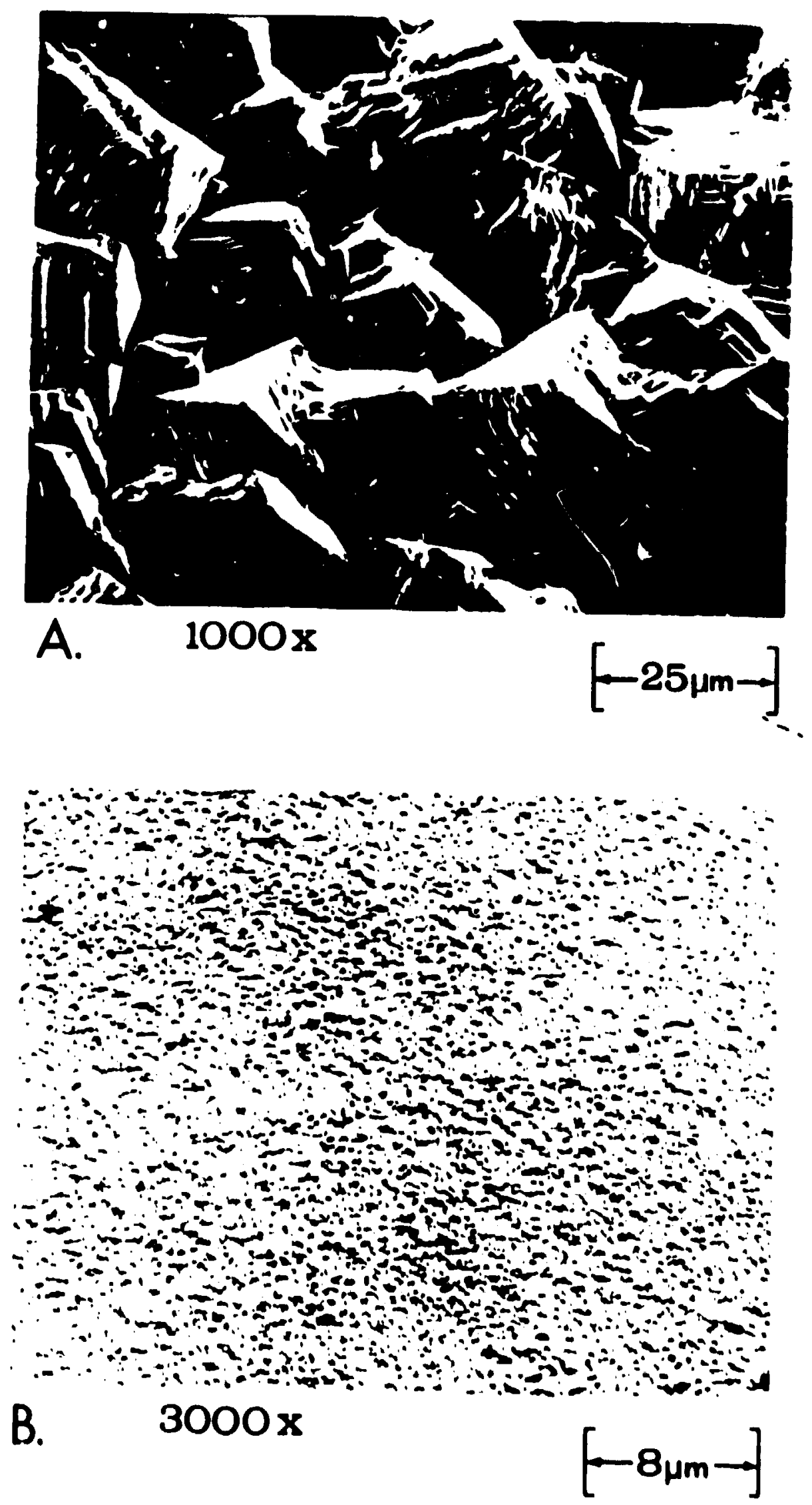

Figure 21 


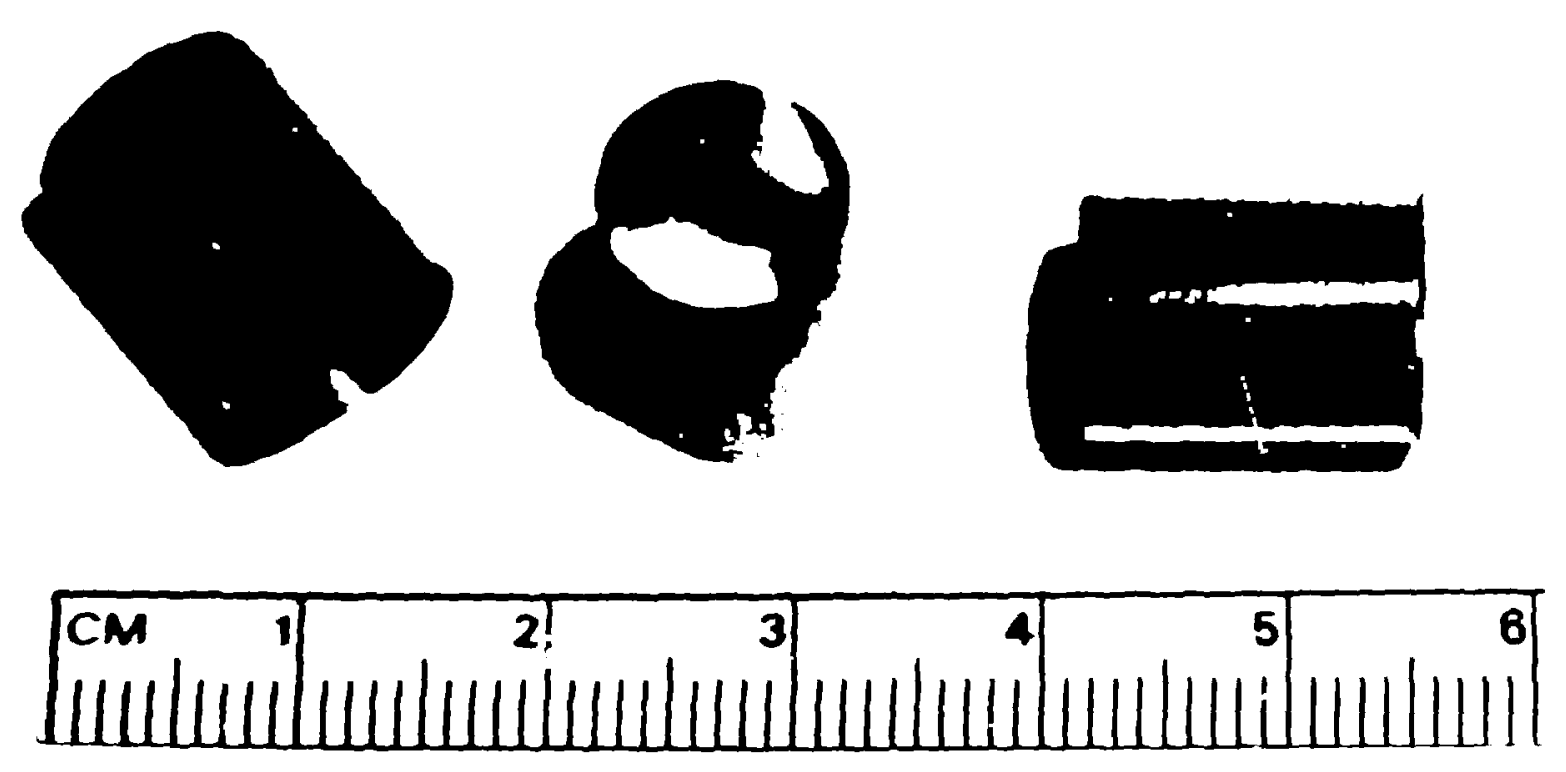

FREESTANDING TUNGSTEN CYLINDERS

\author{
$3.0 \mu \mathrm{m}$ WALL THICKNESS \\ $1.0 \mathrm{~cm}$ DIAM X $1.36 \mathrm{~cm}$ LONG \\ Los Alamos
}

Figure 22 